\title{
Pengembangan Sistem Pengajuan Judul Skripsi Di Jurusan Pendidikan Teknik Elektro Universitas Negeri Makassar Berbasis Website
}

\author{
Humairah \\ Pendidikan Teknik Elektro, Universitas Negeri Makassar \\ Humairah.23megmail.com
}

\begin{abstract}
Abstrak - Penelitian ini adalah penelitian dan pengembangan (R\&D) yang bertujuan untuk mengembangkan sistem informasi pengajuan judul skripsi di Jurusan Pendidikan Teknik Elektro Universitas Negeri Makassar berbasis website. Model pengambangan yang digunakan adalah prototyping dan menggunakan pengujian standar kualitas ISO/IEC 25010 dengan pengujian 5 aspek yakni fungsionality suitability, usability, efficiency, reliability dan maintability. Data dikumpulkan dengan menggunakan pedoman wawancara, dokumantasi dan angket dan data dianalisis menggunakan Teknik analisis statistik deskriptif. Hasil penelitian menunjukkan bahwa sistem pengajuan judul ini telah memenuhi standar ISO/IEC 25010, pada aspek fungsionality bernilai 1 yang berarti bahwa aspek functionality berada dalam kategori "diterima". Pengujian aspek usability dengan jumlah responden sebanyak 40 memperoleh rata-rata persentase kelayakan sebesar $89,25 \%$ dengan kategori "Sangat Layak". Pengujian aspek efficiency page speed sebesar $36 \%$ YsLow sebesar $54 \%$ dan waktu load sebesar 3.16 Pengujian aspek Reliability persentasi kesuksesan dengan menggunakan click test, time test dan ramp test adalah $100 \%$. Pengujian aspek maintainability diperoleh kesimpulan yang mudah diperbaiki apabila terdapat kesalahan.
\end{abstract}

Kata Kunci : ISO/IEC 25010, Pengajuan Judul Skipsi R\&D, Sistem Informasi.

\section{PENDAhuluan}

Kemajuan teknologi komunikasi dan informasi yang paling jelas terlihat saat ini adalah kecepatan dan kemudahan akses yang dapat dinikmati oleh siapa saja. Perubahan dunia yang menuju pada generasi keempat revolusi industri dan berlandaskan pada pemanfaatan teknologi komunikasi dan informasi bagi kebutuhan paling mendasar dari manusia. Kemajuan teknologi adalah hal mutlak dan merupakan sesuatu yang tidak bisa dihindari dalam kehidupan ini, karena kemajuan teknologi akan berjalan sesuai dengan kemajuan ilmu pengetahuan yang senantiasa berkembang, selalu ada inovasi yang bermunculan dan diciptakan dengan tujuan agar dapat memberikan manfaat positif untuk kehidupan peradaban manusia. Sebab pada hakikatnya teknologi diciptakan untuk memudahkan manusia (Kamil. 2018). Menurut Rachmaniar (2017), terdapat beberapa ciri informasi yang berkualitas yakni informasi yang relevan, akurat dan tepat waktu, yang dapat digunakan untuk keperluan pribadi, bisnis, pemerintahan, maupun lembaga non pemerintah.

Teknologi saat ini sangat berdampak pada pola hidup masyarakat dunia mengenai penggunaan teknologi infomasi, salah satunya dapat ditemukan pada bidang pendidikan. Dalam bidang pendidikan, pertemuan langsung secara tatap muka dalam pembelajaran menjadi pendidikan era digital, yang berarti dengan adanya teknologi informasi pelajar dapat mendapatkan ilmu tidak hanya dengan bertatap muka dengan tenaga pendidik, namun dapat mengakses internet untuk mendapatkan materi-materi yang akan dipelajari.

Salah satu komponen yang paling penting digunakan sebagai acuan untuk melihat keberhasilan perguruan tinggi sebagai penyelenggara pendidikan adalah mahasiswa, yang dilihat dari beberapa faktor yakni, Indeks Prestasi Komulatif (IPK), lama masa studi, dan keberhasilan mahasiswa dalam menyelesaikan skripsi (Niswatin, Dkk. 2017)

Universitas Negeri Makassar merupakan salah satu tingkat pendidikan perguruan tinggi yang memiliki sistem informasi yang digunakan oleh mahasiswa yang ada di universitas. Selain itu terciptanya beberapa sistem informasi, khususnya pada Jurusan Pendidikan Teknik Elektro FT UNM yang dapat digunakan seperti, sistem informasi akademik, sistem informasi penggunaan laboratorium, sistem informasi praktek industri, sistem informasi Pendidikan Teknik Elektro, sistem informasi Pendidikan Teknik Informatika dan Komputer. Dengan adanya beberapa sistem informasi tersebut tentunya semakin meningkatkan kualitas pendidikan di Jurusan Pendidikan Teknik Elektro FT UNM. Namun terdapat mekanisme yang rutin dilaksanakan oleh setiap mahasiswa dari seluruh Indonesia termasuk di Universitas Negeri Makassar, yakni penyusunan skripsi. Oleh karena itu penting adanya untuk membuat sistem informasi skripsi yang dimulai dari sistem pengajuan judul di Jurusan Pendidikan Teknik Elektro karena sistem yang diterapkan masih berjalan secara manual baik dari pengajuan, pengetikan judul yang diajukan untuk dirapatkan maupun dari pengumuman judul yang telah dirapatkan yang tidak dapat dilihat hasilnya oleh mahasiswa secara langsung ketika rapat judul telah selesai dilakukan dan tidak adanya pemberitahuan kepada mahasiswa jika judul yang diajukan masuk dalam kategori penolakan.

Berdasarkan penjelasan dari uraian di atas maka penulis berinisiatif membuat sistem informasi pengajuan judul di Jurusan Pendidikan Teknik Elektro. Hal tersebut karena melihat kondisi yang terjadi, yakni sistem pengajuan judul masih menggunakan sistem yang konvensional berdasarkan hasil wawancara yang penulis telah lakukan ke beberapa mahasiswa dan pegawai yang bertugas dalam pengurusan skripsi. Hal tersebut tentunya masih menimbulkan beberapa masalah yang terjadi seperti adanya berkas judul yang tercecer sehingga menghambat untuk disetujui, selain itu juga adanya beberapa kesalahan pengetikan ulang judul yang telah disetujui karena hanya mengetik manual judul oleh operator. Oleh karena, itu penting adanya untuk penulis membuat sebuah sistem yang dapat menyelesaikan permasalahan tersebut dengan pertimbangan dan saran dari dosen pembimbing.

Adanya sistem yang berbasis digital segala pengurusan judul skripsi dapat dilakukan dengan mudah, dilihat dari sisi mahasiswa yang dapat dengan mudah memasukkan judul yang akan diajukan, adanya format berkas untuk tanda tangan ketua prodi dan pembimbing akademik yang dapat didapatkan langsung pada sistem, serta adanya informasi yang didapatkan langsung oleh mahasiswa mengenai status judul yang telah diajukan. Dari sisi staf Jurusan Pendidikan Tekni Elekrto FT UNM dapat mengurangi 
beban pekerjaan dari pengetikan dan persiapan berkas mahasiswa yang akan dirapatkan oleh tim seleksi judul, dan dari sisi tim seleksi judul dapat melihat berkas yang diupload oleh mahasiswa dan dapat memverifikasi langsung ketiga judul yang diajukan oleh mahasiswa, baik dalam memilih judul yang akan diterima, memilih dosen pembimbing dan dosen penguji maupun memberikan komentar kepada mahasiswa mengenai judul yang diterima maupun judul yang ditolak dan data akan masuk dalam pemberitahuan akun mahasiswa. Sehingga peneliti mengembangkan sistem pengajuan judul skripsi di Jurusan Pendidikan Teknik Elekro Universitas Negeri Makassar berbasis website.

\section{TINJAUAN PUSTAKA}

\section{A. Penelitian Pengembangan}

Research and Development (R\&D) adalah metode penelitian yang digunakan untuk menghasilkan produk tertentu dan menguji keefektifan metode tersebut. Dalam bidang pendidikan, penelitian dan pengembangan atau Research and Development (R\&D), merupakan metode penelitian yang digunakan untuk mengembangkan atau memvalidasi produk-produk yang digunakan dalam pendidikan dan pembelajaran. Dari uraian tersebut maka dapat ditarik kesimpulan bahwa Research and Development adalah metode penelitian yang bertujuan untuk menghasilkan produk-produk tertentu serta menguji validitas dan keefektifan produk tersebut dalam penerapannya.

\section{B. Model Pengembangan Perangkat Lunak}

1. Model Prototyping

Menurut Ogedebe. Dkk (2012), Prototyping merupakan metode pengembangan perangkat lunak yang berupa model fisik kerja sistem dan berfungsi sebagai versi awal dari sistem. Dengan menggunakan metode Prototyping akan menghasilkan prototype sistem sebagai perantara pengembang dan pengguna agar dapat berinteraksi dalam proses pengembangan sistem informasi

\section{Waterfall}

Model pengembangan waterfall merupakan model pengembangan sistem informasi yang sistematik dan sekuensial (Pressman. 2002). Model pengembangan waterfall bersifat linear dari tahap awal pengembangan sistem yaitu pada tahap perencanaan sampai pada tahap akhir pengembangan sistem yaitu tahap pemeliharaan

\section{Pengujian Perangkat Lunak}

Saat ini terdapat berbagai macam standar pengujian perangkat lunak diantaranya McCall, Boehm, Frups, Dromey, Bertio, ISO 9126 dan ISO 25010. Namun, dari berbagai standar pengujian tersebut, ISO 9126 dan ISO 25010 merupakan pengujian dengan standar internasional dalam pengujian perangkat lunak. Menurut Prof. Azuma dalam konferensi software testing di SOFTEC Malaysia menyebutkan bahwa standar ISO 25010 dikembangkan untuk mengantikan ISO 9126 didasarkan pada berkembangan ICT (Information and Communication Technology) seperti perkembangan mikroprosesor, perkembangan memori, perkembangan tampilan, dan perkembangan media penyimpanan.

Metode ISO 25010 dapat dilakukan untuk mengukur kualitas sistem aplikasi dengan menggunakan dua dimensi umum yaitu product quality dan quality in use. Dimensi Product Quality, di mana prosesnya mengacu pada karakteristik intrinsik dari sebuah produk perangkat lunak, memiliki beberapa elemen antara lain meliputi functional suitability, reliability, operability, performance efficiency, security, compatibility, maintainability dan transferability. Quality in use dan product quality. Sedangkan pada dimensi Quality in Use, terdapat beberapa karakteristik relatif yang ditinjau dari perspektif user antara lain Usability in use, Flexibility in use, dan Safety (Alfian. 2017).

\section{III.METODE PENELITIAN}

A. Jenis Penelitian

Jenis penelitian yang digunakan adalah penelitan $\mathrm{R} \& \mathrm{D}$ (Research and development). R\&D dapat diartikan sebagai cara ilmiah untuk meneliti, merancang, memproduksi dan menguji validitas prodak yang telah dihasilkan. Produk yang dihasilkan adalah sistem pengajuan judul skripsi di jurusan Pendidikan Teknik Elektro Universitas Negeri Makassar berbasis web. R \& D dipahami sebagai penelitian yang dimulai dengan research dan diteruskan dengan development. Kegiatan research dilakukan untuk mendapatan informasi tentang kebutuhan pengguna (needs assesment). Penulis melakukan research yaitu berupa skripsi, jurnal, beberapa artikel, observasi dan wawancara langsung kepada pegawai yang bertugas. Sedangkan kegiatan development dilakukan dengan menghasilkan suatu sistem.

\section{B. Model Pengembangan}

Model pengembangan yang digunakan dalam penelitian ini adalah model prototyping dimana model yang digunakan, karena modek ini sangat cocok digunakan dalam pengembangan sistem informasi dengan menggunakan alur yang mudah untuk dipahami. Rancangan alur yang digunakan mengacu pada rancangan prototyping yang digunakan oleh Pressman pada tahun 2012.

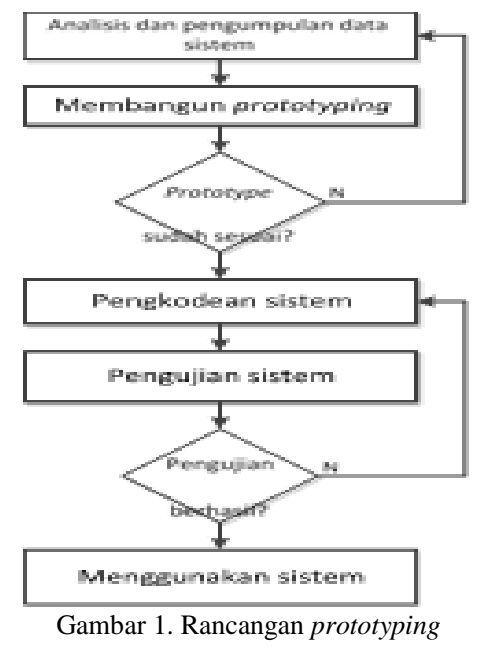

\section{Prosedur Perancangan Sistem}

1. Analisis Kebutuhan

Berdasarkan analisis yang telah dilakukan oleh penulis maka dapat diketahui apa saja yang menjadi masukan sistem, keluaran sistem, metode yang akan digunakan, serta tampilan antar muka yang akan dibuat. Hal tersebut guna untuk memastikan sistem yang akan dibuat sesuai dengan yang diharapkan. Setelah data dan informasi terkumpul maka dilakukan analisis data yang meliputi data teknik dan non teknis. Data-data teknik selanjutnya akan digunakan untuk kebutuhan perencanaan teknis sistem registrasi, seperti konfigurasi, requirement hardware, software, dan interface dan non teknis akan digunakan untuk mendukung kebijakan sistem informasi pengajuan judul skripsi. Hasil observasi diperoleh sebagai informasi dan sebagai aturan yang akan digunakan pada sistem adalah sebagai berikut :

a. Admin merupakan petugas yang bertanggung jawab yang mengontrol jalannya sistem.

b. Operator merupakan pengguna dan petugas yang terdiri dari tim seleksi judul yang bertugas dalam mengoperasikan 
komputer ketika sedang dilaksanakan rapat pemilihan judul

c. Tim seleksi judul merupakan dosen yang bertugas untuk menetapkan disetujui dan tidaknya judul mahasiswa yang telah mengajukan pada sistem

d. Mahasiswa Jurusan Pendidikan Teknik Elektro yang merupakan pengguna sistem

2. Subjek Uji Coba

Uji coba sistem akan dilakukan pada mahasiswa yang telah mengajukan judul di Jurusan Pendidikan Teknik Elektro FT UNM, hal tersebut berdasarkan pertimbangan bahwa yang responden telah mengetahui cara pengurusan judul dengan metode yang telah diterapkan sebelumnya. Adapun jumlah responden yang menjadi objek ujicoba sebanyak 20 orang dari Prodi Pendidikan Teknik Informatika dan Komputer dan 20 orang dari Prodi Pendidikan Teknik Elektro Fakultas Teknik UNM.

\section{Teknik Pengumpulan Data}

Teknik pengumpulan data yang digunakan dalam penelitian ini adalah:

1. Wawancara

Wawancara dilakukan sebagai studi pendahuluan untuk menghasilkan data penelitian awal yang dilakukan oleh penulis, wawancara dilakukan langsung di Jurusan Pendidikan Teknik Elektro FT UNM yang lebih spesifik pada staf yang bertugas dalam pengajuan judul mahasiswa di Jurusan Pendidikan Teknik Elektro FT UNM, dengan menggunakan pedoman wawancara sebagai alat pengumpulan data.

2. Dokumentasi

Teknik dokumentasi yang dilakukan pada penelitian ini adalah foto pada saat ujicoba sistem dan dokumen yang didapatkan pada saat pengujian sistem menggunakan aspek maintainability menggunakan foto pada sistem, aspek efficiency dan reliability menggunakan dokumen pdf pada hasil analisis data.

3. Angket

Angket yang digunakan dalam penelitian ini adalah kuisioner merupakan teknik pengumpulan data yang dilakukan dengan cara memberi seperangkat pertanyaan atau pernyataan terlulis kepada responden. Peneliti dapat menggunakan kuisioner untuk memperoleh data yang terkait dengan pemikiran, perasaan, sikap, kepercayaan, nilai, persepsi, kepribadian, dan perilaku dari responden. Anket diberikan pada pengujian perangkat lunak dari aspek karakteristik functionality dan usability. Instrumen usability diadopsi dari kuisioner yang digunakan USE Questionnaire oleh Arnol M.Lund 2001

\section{E. Rancangan Sistem}

Pada tahap ini peneliti membuat perancangan sementara yang berfokus pada penyajian kepada user dengan membuat use case, activity diagram, flowchart dan perancangan antarmuka (interface). Pada dasarnya activity diagram sering digunakan oleh flowchart. Diagram ini berhubungan dengan statechart diagram. Statechart diagram berfokus pada objek yang dalam suat proses, atau proses menjadi suatu objek. Activity diagram berfokus pada aktivitas-aktivitas yang terjadi terkait dalam suatu proses tunggal. Jadi dengan kata lain, diaram ini menunjukkan bagaimana aktifitas-aktifitas tersebut bergantung satu sama lain dan Activity diagram adalah salah satu cara untuk memodelkan event-event yang terjadi dalam suatu use case.

\section{F. Instrumen Penelitian}

Instrumen penelitian yang digunakan dalam penelitian ini berdasarkan pengujian menggunakan aspek fungsionality suitability, usability, efficiency, reliability dan maintability.

\section{Functional Suitability}

Instrumen penelitian berupa checklist pada test case yang berisi daftar fungsi aplikasi yang dijabarkan sesuai analisis kebutuhan fungsional. Pengujian test case dilakukan oleh responden ahli dengan kriteria responden memiliki pekerjaan sehari-hari sebagai pengembang sistem. Dari test case ini didapatkan hasil pengujian functional correctness. Sedangkan pernyataan kesimpulan dari para ahli setelah melakukan pengujian functional correctness merupakan functional completeness dan functional appropriateness

\section{Usability}

Uji usability pada pengembangan sistem informasi pengajuan judul skripsi di Jurusan Pendidikan Teknik Elektro FT UNM menggunakan kuesioner yang diberikan kepada pengguna. Di mana pengguna mengisi kuesioner berdasarkan dengan ujicoba yang telah dilakukan pada sistem secara langsung. Kuesioner terlebih dahulu divalidasi oleh validator agar kuesioner yang digunakan dapat dipahami dengan mudah oleh responden. Responden dalam pengujian ini minimal berjumlah 20 orang agar didapatkan angka yang signifikan secara statistik.

3. Efficiency

Pengujian pada aspek ini menggunakan alat ukur GTMetrix. Pengujian dilakukan dengan load testing menggunakan software GTMetri yang akan menghasilkan performance scores yang meliputi page speed score dan Yslow score serta page details yang meliputi fully load time, total page size, dan request.

\section{Reliability}

Pengujian reability dilakukan dengan stress testing menggunakan software Webserver Stress tool 8 memberikan sejumlah beban kepada perangkat lunak sehingga dapat diketahui apakah perangkat lunak berjalan baik saat diberi beban.

\section{Maintability}

Pengujian pada aspek ini menggunakan ukuran yang diuji oleh peneliti langsung di lapangan secara operasional. Sesuai dengan instrumen pengujian maintainability Land, pengujian ini meliputi 3 aspek, yaitu instrumenation, consistency dan simplicity.

\section{G. A. Teknik Analisis Data}

Berdasarkan pengujian yang digunakan yaitu ISO 25010 adapun teknik analisis data yang dilakukan yang meliputi empat aspek adalah:

1. Analisis Konten

Analisis untuk validitas konten dilakukan dengan skala likert. Skala likert merupakan jenis skala yang digunakan untuk mengukur sikap, pendapat, dan persepsi seseorang atau kelompok. Adapun kriteria pemberian skor untuk alternatif jawaban untuk setiap item sebagai berikut: (1) skor 5 untuk jawaban sangat baik, (2) skor 4 untuk jawaban baik, (3) skor 3 untuk jawaban cukup, (4) skor 2 untuk jawaban kurang, (5) skor 1 untuk jawaban sangat kurang. Pengkategorian hasil analisis ahli materi dilakukan berdasarkan kriteria pengkategorian kualitas materi yang diadaptasi dari Azwar 2010, sebagai berikut:

Tabel 1. Kategori Pemberian Skor Alternatif Jawaban Ahli Instrumen

\begin{tabular}{|l|l|}
\hline \multicolumn{1}{|c|}{ Skor } & Kategori \\
\hline $4,2 \leq M \leq 5,0$ & Sangat Layak \\
\hline $3,4 \leq M<4,2$ & Layak \\
\hline $2,6 \leq M<3,4$ & Cukup Layak \\
\hline $1,8 \leq M<2,6$ & Kurang Layak \\
\hline $1,0 \leq M<1,8$ & Tidak Layak \\
\hline
\end{tabular}

(Sumber: Azwar. 2010) 


\section{Fungsionality}

Berdasarkan deskripsi dari aspek fungsionality, maka pengujuan dilakukan dengan checklist daftar fungsi untuk melihat kesesuaian kesatuan fungsi dalam melakukan tugas tertentu, pengujian dilakukan oleh 2 validator ahli di bidang aplikasi web. Pengujian dilakukan untuk melihat kevalidan sistem yang meliputi interfaces mahasiswa, admin dan Tim seleksi judul. Skala pengukuran dengan tipe ini akan didapat jawaban yang tegas yaitu ya-tidak, benar-salah, pernah-tidak pernah, positif-negatif. Jawaban dapat dibuat dalam bentuk checklist dengan skor tinggi satu dan skor rendah nol. Hasil skor tersebut kemudian dihitung dengan matriks Feature Completeness yang digagas oleh Archarya dan Sinha untuk mengukur sejauh mana fitur-fitur yang ada di desain dapat benar-benar di implementasikan. Berikut adalah rumus perhitungan Feature Completeness.

Persentase Functionality $=\frac{\text { Skor yang diperoleh }}{\text { Skor maksimal }} \times 100 \%$

Hasil dari perhitungan Feature Completeness kemudian diukur dengan interprestasi Feature Completeness, yaitu hasil nilai $\mathrm{x}$ yang mendekati angka mengindikasikan bahwa hampir semua fitur yang didesain berhasil di implementasikan. Sehingga pengujian karakteristik functionality dikatakan baik, jika hasil $\mathrm{X}$ mendekati $1(0 \leq \mathrm{x} \leq 1)$, dengan hasil persentase seperti di bawah ini:

Tabel 2. Persentase Functionality

\begin{tabular}{|c|c|}
\hline Persentase Kelayakan & Kriteria \\
\hline $81 \%-100 \%$ & Sangat Baik \\
\hline $61 \%-80 \%$ & Baik \\
\hline $41 \%-60 \%$ & Cukup \\
\hline $21 \%-40 \%$ & Kurang \\
\hline$<20 \%$ & Sangat Kurang \\
\hline
\end{tabular}

Sumber (Guritno, 2011)

\section{Usability}

Pengguna akan memberikan penilaian kelayakan berdasarkan angket yang diberikan menggunakan skala likert. Skala likert meliputi, Sangat Setuju (SS), Setuju (S), Ragu- ragu (R), Tidak Setuju (TS), Sangat Tidak Setuju (STS). Skor untuk pertanyaan favourable dimulai dari sangat positif sampai sangat negatif begitupun sebaliknya untuk pertanyaan unfavourable. Perhitungan persentase usability sebagai berikut:

Hasil yang didapatkan dari persentase kemudian dibandingkan dengan menggunakan skala Likert. Pengelompokan tingkat presentase sesuai skala Likert dapat dilihat pada tabel di bawah:

Tabel 3. Persentase Kelayakan

\begin{tabular}{|c|l|}
\hline Persentase Kelayakan & \multicolumn{1}{|c|}{ Kriteria } \\
\hline $81 \%-100 \%$ & Sangat Layak \\
\hline $61 \%-80 \%$ & Layak \\
\hline $41 \%-60 \%$ & Cukup \\
\hline $21 \%-40 \%$ & Kurang \\
\hline$<20 \%$ & Sangat Kurang \\
\hline
\end{tabular}

Sumber (Guritno, 2011)

4. Efficiency

Pengujian performance efficiency dilakukan dengan load testing menggunakan GTMetrix. Web dikatakan baik apabila waktu load setidaknya kurang dari 10 detik.

5. Reliability

Pengujian reliability dilakukan dengan stress testing yang harus memenuhi standar Telcordia yaitu minimal $95 \%$.

6. Maintainability
Karakter kualitas aspek maintainability diukur menggunakan metrics pengujian maintainability yang menghasilkan konsisi dari pengujian yang dilakukan secara operasional di lapangan. Jika web yang diuji lolos untuk semua aspek dalam instrumen maka web dinyatakan memenuhi uji aspek maintainability

\section{IV.HASIL PENELITIAN DAN PEMBAHASAN}

A. Hasil Penelitian

Hasil penelitian ini berupa sistem pengajuan judul skripsi di Jurusan Pendidikan Teknik Elektro Universitas Negeri Makassar Berbasis Website. Sistem yang dibuat menggunakan php, html,css dan javacript dengan menggunakan software sublime text dan framework bootstrap. Pengembangan dalam sistem ini bertujuan untuk membuat sistem pengajuan judul skripsi di Jurusan Pendidikan Teknik Elektro FT UNM berbasis website yang dapat memudahkan dalam pengurusan judul di Jurusan Pendidikan Teknik Elektro FT UNM, sistem tersebut dilengkapi fitur berdasarkan dengan prosedur yang dilakukan baik pada mahasiswa maupun tim seleksi judul sampai dengan pengumuman judul mahasiswa. Sistem informasi ini dinamakan SIMPEL, di mana kata SIMPEL merupakan singkatan dari kata sistem informasi pengajuan judul. Berdasarkan model penelitian yang digunakan yakni prototyping, adapun hasil dari prosesnya sebagai berikut:

1. Analisis dan Pengumpulan data sistem

Analisis dan pengumpulan data sistem dilakukan dengan wawancara dan observasi langsung di jurusan Pendidikan Teknik Elektro FT UNM, wawancara dilakukan dengan menggunakan pedoman wawancara yang telah dikonsultasikan pada pembimbing sebelum dilakukan wawancara. Wawancara dilakukan kepada dua dosen yang termasuk tim seleksi judul, satu orang staf jurusan Pendidikan Teknik Elektro FT UNM dan beberapa mahasiswa di Jurusan Pendidikan Teknik Elektro FT UNM. Berikut adalah format seluruh sistem informasi pengajuan judul yang akan dikembangkan, mengidentifikasikan seluruh kebutuhan, dan garis besar sistem yang akan dibuat:

a Tim seleksi judul di Jurusan Pendidikan Teknik Elektro FT UNM menilai bahwa sistem pengajuan judul skripsi sangat dibutuhkan untuk membantu dalam proses pengajuan judul yang lebih baik.

b. Tim seleksi judul, staf jurusan dan mahasiswa di Jurusan Pendidikan Teknik Elektro FT UNM menilai bahwa pemanfaatan teknologi dan komunikasi dalam pengajuan judul skripsi dapat mempermudah, mempercepat dan meminimalisir terjadinya kesalahan yang terjadi ketika pengurusan pengajuan judul skipsi.

c. Level akses (user) terdiri dari admin, tim seleksi judul dan mahasiswa

d. Data yang dimasukkan yakni data mahasiswa berupa nama, nim, prodi dan data judul, sedangkan tim seleksi seperti nama dan golongan. Serta juga dimasukkan data dari pembimbing akademik untuk keperluan berkas dari mahasiswa dan pada data verifikasi dari judul yang akan diumumkan.

e. Admin dapat menambah, menghapus, pengubah, mencari dan mencetak data hasil seleksi.

f. Tim seleksi dapat melakukan seleksi judul yang akan diterima, ditolak maupun judul yang disarankan.

g. Mahasiswa dapat mengajukan judul,mendownload dan mengupload berkas pengajuan judul skripsi serta melihat status dari judul yang diajukan.

2. Membangun Prototyping

Berdasarkan hasil dari analisis dan pengumpulan data awal langkah selanjutnya adalah membangun prototyping yang dilakukan dengan membuat rancangan sementara yang berfokus dengan penyajian kepada admin. Rancangan terdiri dari rancangan 
sistem, rancangan tabel, rancangan interfaces dan rancangan jaringan yang telah dijelaskan pada bab III halaman 53-68. Jika prototype yang dirancang sesuai telah sesuai maka proses dilanjutkan.

3. Evaluasi Prototyping

Setelah prototyping telah selesai dibangun, dilanjutkan dengan evaluasi prototyping yang dilakukan kepada calon user terkhusus pada operator jurusan di Pendidikan Teknik Elektro yang akan menggunakan sistem, berikut adalah

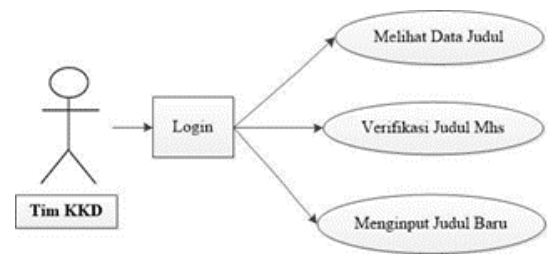

Gambar 2. Usecase Sebelum Dievaluasi

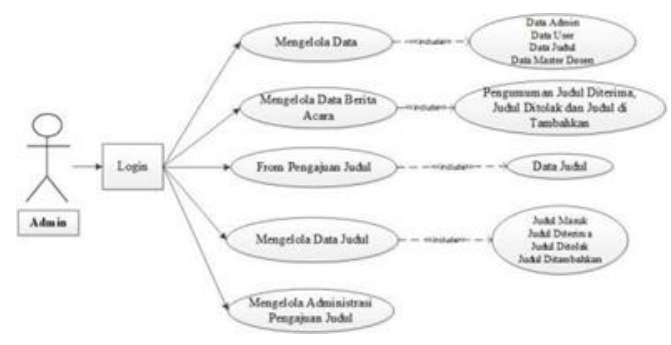

Gambar 3. Usecase Setelah Dievaluasi

\section{Pengkodean Sistem}

Pada tahap ini prototyping yang telah disepakati diterjemahan ke dalam bahasa pemprograman yang sesuai. Bahasa pemprograman web yang digunakan adalah hypertext preprocessor (PHP), HTML dan Java Script, dan sistem pengolahan database menggunakan MySQL. Berikut adalah tampilan dari beberapa script yang digunakan dalam pengemabangan sistem dan pengolahan database. Hasil coding sistem ditunjukkan pada bagian berikut ini:

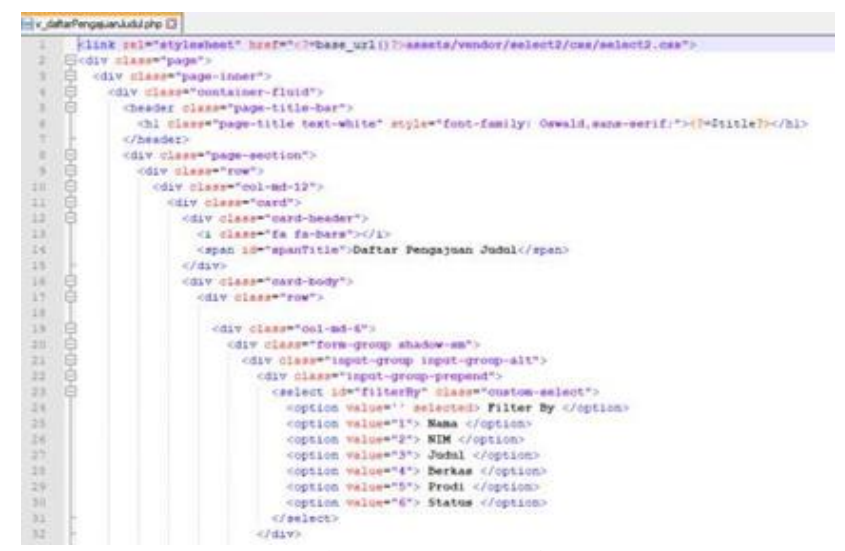

5. Pengujian Sitem

Gambar 4. Script Pengajuan

Pengujian sistem dilakukan dengan menggunakan ISO/IEC 25010 dengan menggunakan 5 aspek pengujian, serta melakukan pengujian untuk melihat konten yang dimuat telah sesuai berikut adalah hasil pengujiannya

a. Pengujian Konten

Validasi konten dilakukan dengan menggunakan skala Likert.
Terdapat 12 item pernyataan yang wajib diisi oleh validator konten, di mana pernyataan tersebut dapat dilinai dengan skor 1-5 yang menyatakan masing-masing kriteria pada setiap nomor pernyataannya. Berikut adalah hasilnya

Tabel 4. Hasil pengujian konten

\begin{tabular}{|c|c|c|c|c|}
\hline No & $\begin{array}{c}\text { Butir } \\
\text { Pertanyaan }\end{array}$ & $\begin{array}{c}\text { Jumlah } \\
\text { Skor }\end{array}$ & $\begin{array}{l}\text { Rata- } \\
\text { rata }\end{array}$ & Kategori \\
\hline 1 & Validator 1 & 60 & 5 & Sangat layak \\
\hline 2 & Validator 2 & 47 & 3,92 & Layak \\
\hline \multicolumn{3}{|c|}{ Rata-rata } & 4,46 & Sangat layak \\
\hline
\end{tabular}

Pada tabel validasi konten tabel 4 menunjukan validasi konten yang dilakukan oleh 2 orang ahli validator mendapatkan rerata skor 4.46, sehingga bisa disimpulkan bahwa SIMPEL memenuhi validasi konten dengan kategori sangat layak.

b. Pengujian ISO/IEC 25010

\section{1) Functionality}

Pengujian functionality dilakukan dengan melibatkan dua ahli yang berpengalaman dibidang sistem informasi khususnya website. Ahli menguji sistem secara langsung dengan mencoba semua fungsi didalamnya, kemudiann mengisikan hasil pengujian berdasarkan instrument yang diberikan oleh peneliti. Hasil data pengujian functionality sebagai berikut:

Tabel 5 Data hasil pengujian Functionality Sistem

\begin{tabular}{|c|c|c|}
\hline \multirow{2}{*}{ Jawaban } & \multicolumn{2}{|c|}{ Skor Oleh Validator } \\
\cline { 2 - 3 } & Validator 1 & Validator 2 \\
\hline Ya & 24 & 24 \\
\hline Tidak & - & - \\
\hline
\end{tabular}

Berdasarkan hasil pada Tabel 5 dapat diketahui rata-rata persentase untuk masing-masing penilaian adalah: $\mathrm{X}=\frac{1}{P}$

Keterangan :

$\mathrm{I}=$ Jumlah fitur yang berhasil di implementasikan

$\mathrm{P}=$ Jumlah fitur yang didesain

Karena Validator 1 dan validator 2 dengan hasil 24 maka Testing Criteria bernilai 1. Hal ini berarti bahwa aspek functionality sistem informasi yang dikembangkan berada pada kategori receptable (dapat diterima).

\section{2) Usability}

Pengujian usability dilakukan dengan menggunakan metode penyebaran angket yang diisi oleh 20 mahasiswa di prodi Pendidikan Teknik elektro dan 20 mahasiswa pada prodi Pendidikan Teknik informatika dan komputer, hal tersebut dilakukan karena sistem akan diterapkan di jurasan Pendidikan Teknik elektro sehingga responden diambil secara purposif dengan kategori mahasiswa yang telah mengajukan judul, hal tersebut dilakukan karena pengujian usability dilakukan untuk melihat sejauh mana pengguna dapat berinteraksi secara efektif dan melihat tingkat kepuasan pengguna dalam menggunakan sistem, oleh sebab itu responden diambil dari mahasiswa yang telah melakukan pengajuan judul.

Persentase usability $=\frac{\text { Skor yang diperoleh }}{\text { Skor maksimal }} \times 100 \%$
Persentase usability $=5355 / 6000 \times 100 \%$
Persentase usability $=89,25 \%$ 
Tabel 6. Analisis Statistik Deskriptif

\begin{tabular}{|c|l|c|c|c|}
\hline Interval & Kategori & $\begin{array}{c}\text { Jumlah } \\
\text { Responden }\end{array}$ & $\begin{array}{c}\text { Persentase } \\
\text { Relatif \% }\end{array}$ & $\begin{array}{c}\text { Persentase } \\
\text { Komulatif }\end{array}$ \\
\hline $126-150$ & Sangat Layak & 35 & 87.5 & 35 \\
\hline $102-126$ & Layak & 4 & 10 & 39 \\
\hline $78-102$ & Cukup & 1 & 2.5 & 40 \\
\hline $54-78$ & Kurang & 0 & 0 & 0 \\
\hline $30-53$ & Sangat Kurang & 0 & 0 & 0 \\
\hline
\end{tabular}

Berdasarkan dari analisis perhitungan akhir diperoleh persentase $89,25 \%$ dalam pengujian usability dari 40 orang responden dengan hasil perhitungan sangat Layak dengan persentase $100 \%$. Selain itu berdasarkan hasil analisis analisis deskriptif menunjukkan bahwa nilai minimum senilai 89 dan nilai maximum 150, dengan rata-rata 133,88 dan standar deviasi 9,202. Dari data tersebut menunjukkan bahwa rata-rata lebih besar dari pada standar deviasi yang menunjukkan bahwa data usability dapat diterima.

\section{3) Reliability}

Pengujian reliability yang dilakukan pada sistem informasi salah satunya dengan menggunakan metode stress testing, di mana stress testing merupakan pengujian yang menentukan ketahanan suatu software dengan menguji di luar batas penggunaan normal. Tujuan utama dalam melakukan pengujian ini adalah untuk memaksa suatu program terjadi crash dan mengetahui bagaimana program dapat bekerja kembali secepatnya, crash dapat disebabkan karena banyaknya permintaan akses dari user yang banyak dalam waktu bersamaan. Stress testing dalam pengujian ini menggunakan software Webserver Stress Tool, yang memiliki tiga aspek tes, yakni click test, time test dan ramp test. Click test adalah aksi yang dilakukan untuk menguji ketahanan sistem yang kemudian setiap aksi klik akan dihitung jeda waktu dan pengiriman yang dapat dilakukan oleh server jika diakses secara bersamaan.

4) Click Test

Dengan menggunakan load konstan sehingga user memenuhi jumlah klik yang telah digenerasi. Berikut adalah hasil click test dengan jumlah run until 10 click per user, sebanyak 10 user yang mengakses dengan click delay 5 seconds. Hasil yang diperoleh dalam pengujian click test per user dan per url menunjukkan bahwa jumlah click yang diberikan sebanyak 10 kali dengan jumlah hits 10 dengan error yang terjadi sebanyak 0, untuk waktu yang digunakan paling cepat $250 \mathrm{~ms}$, kecepatan bytes mencapai 72,460 dan kecepatan akses mencapai 300,37 kbit/s.

\section{5) Time Test}

run test dengan jumlah load konstan pada waktu yang telah ditentukan. Pengujian time test dilakukan dengan jumlah waktu 30 menit, dengan jumlah virtual user 10 orang dan waktu delay 5 detik. Hasil yang diperoleh dengan pengujian time test dengan jumlah load konstan pada waktu yang telah ditentukan. Pengujian time test dilakukan menghasilkan jumlah click terbesar sebanyak 290, waktu klik mencapai $1.399 \mathrm{~ms}$, kecepatan bytes sebesar 2.499 .787 dan untuk kecepatan akses mencapai 60,46 kbit/s. Terjadi error di user ke 10 pada time test per user, namun pada hasil Time Test per Url jumlah error tidak terdapat, hal tersebut kemungkinan karena jumlah error yang dideteksi tidak terlalu signifikan, hal tersebut telah peneliti lakukan observasi pengujian time test sebanyak empat kali pengujian, namun hasil yang didapatkan berbeda setiap pengujiannya.

6) Ramp Test

Ramp Test: Run test dengan jumlah load yang semakin meningkat pada waktu yang telah ditentukan. Ramp Test dilakukan pada waktu 30 menit dengan jumlah virtual user 10 orang dan waktu delay 5 second. Run test dengan jumlah load yang semakin meningkat pada waktu yang ditentukan. Ramp test dilakukan menghasilkan jumlah klik terbesar sebanyak 340 dengan hits 339, dari pengujian ramp test tidak didapatkan error yang terjadi, dengan kecepatan bytes mencapai 2.456.394 dan untuk kecepatan aksesnya $276,53 \mathrm{kbit} / \mathrm{s}$.

Tabel 7. Hasil Pengujian Reliability

\begin{tabular}{|l|l|l|}
\hline Jenis Tes & Persentase Error per URL & $\begin{array}{c}\text { Persentase Sukses } \\
\text { per URL }\end{array}$ \\
\hline Click Test & $0 \%$ & $100 \%$ \\
\hline Time Test & $0 \%$ & $100 \%$ \\
\hline Ramp Test & $0 \%$ & $100 \%$ \\
\hline Rata-rata & $\mathbf{1 0 0 \%}$ \\
\hline
\end{tabular}

Berdasarkan hasil pengujian reliability pada tabel 7 , dapat disimpulkan bahwa persentasi kesuksesan dari pengujian reliability dengan menggunakan click test, time test dan ramp test adalah $100 \%$ dapat diterima, karena telah memenuhi standar Telcordia yaitu minimal keberhasilan $95 \%$.

7) Efficiency

Pengujian sistem SIMPEL pada aspek efficiency dilakukan untuk melihat tingkat efisiensi performa dari aplikasi yang dikembangkan. Proses pengujian dilakukan dengan bantuan software GTMetrix. Hasil Pengujian menunjukkan bahwa rata-rata untuk page speed sebesar $36 \%$ YsLow sebesar $54 \%$ dan waktu load sebesar 3.16 detik. Web dikatakan baik apabila waktu load setidaknya kurang dari 10 detik. Dari hasil tersebut sehingga dapat disimpulkan bahwa SIMPEL telah memenuhi karakteristik performance efficiency.

\section{8) Maintainability}

Pengujian pada aspek maintainability menggunakan ukuran yang diuji oleh peneliti langsung di lapangan secara operasional, sesuai dengan instrument pengujian yang disebutkan oleh Land, pengujian ini meliputi 3 aspek yaitu instrumentation, consistency dan simplicity. Hasil dari pengujian maintainability dapat dilihat pada gambar di bawah apabila terjadi kesalahan input atau masukan yang digunakan oleh pengguna, maka sistem akan secara otomatis memberikan pesan peringatan.

\begin{tabular}{|c|l|l|}
\hline Aspek & Penilaian & \multicolumn{1}{c|}{ Hasil } \\
\hline Instrumentation & $\begin{array}{l}\text { Terdapat } \\
\text { peringatan } \\
\text { dari sistem } \\
\text { jika terjadi } \\
\text { kesalahan } \\
\text { beserta } \\
\text { identifikasi } \\
\text { kesalahan }\end{array}$ & $\begin{array}{l}\text { Ketika ada kesalahan yang dilakukan } \\
\text { oleh } \text { user, sistem mengeluarkan } \\
\text { peringatan untuk mengidentifikasi } \\
\text { kesalahan. Contoh, ketika } \text { user } \\
\text { memasukkan data baru dalam } \\
\text { banyak field dan masih ada field yang } \\
\text { kosong maka akan muncul } \\
\text { peringatan agar melengkapai data. }\end{array}$ \\
\hline Consistency & $\begin{array}{l}\text { Penggunaan } \\
\text { satu model } \\
\text { rancangan } \\
\text { pada seluruh } \\
\text { rancangan } \\
\text { sistem }\end{array}$ & $\begin{array}{l}\text { Model rancangan sistem telah } \\
\text { mempunyai satu bentuk yang sama. } \\
\text { Hal ini dapat dilihat pada bagian } \\
\text { halaman web dari satu halaman ke } \\
\text { halaman lainnya memiliki } \\
\text { kemiripan, bentuk yang serupa, dan } \\
\text { konsisten. }\end{array}$ \\
\hline
\end{tabular}




\begin{tabular}{|l|l|l|}
\hline Simplicity & $\begin{array}{l}\text { Kemudahan } \\
\text { dalam } \\
\text { pengelolaan, } \\
\text { perbaikan, } \\
\text { dan } \\
\text { pengembang } \\
\text { an sistem }\end{array}$ & $\begin{array}{l}\text { Hasil pengujian menunjukan bahwa } \\
\text { sistem mudah untuk diperbaiki dan } \\
\text { dikembangkan, karena dibuat } \\
\text { menggunakan framework PHP } \\
\text { berbasis ModelView- Controller } \\
\text { (MVC). Jika ingin menambah fungsi, } \\
\text { pengembang hanya perlu membuat } \\
\text { controller baru tanpa mengubah } \\
\text { komponen sistem yang lain. Ketika } \\
\text { ditemukan error pada fungsi sistem, } \\
\text { kesalahan dapat ditelusuri hanya } \\
\text { pada bagian komponen modul/ } \\
\text { controller yang bermasalah. } \\
\text { Contohnya jika fungsi penyimpanan } \\
\text { data tidak dapat berfungsi dengan } \\
\text { baik, pengembang hanya perlu } \\
\text { mencari kesalahan pada komponen } \\
\text { modul penyimpanan data itu saja. }\end{array}$ \\
& \\
&
\end{tabular}

\section{B. Pembahasan}

Sistem pengajuan judul skripsi dalam penelitian ini berupa sistem yang dirancang untuk memberikan kemudahan kepada mahasiswa, staf dan tim seleksi judul di Jurusan Pendidikan Teknik Elektro Universitas Negeri Makassar dalam pegurusan/pengajuan judul untuk melengkapi tugas akhir kuliah. Sistem pengajuan judul skripsi (SIMPEL) ini dirancang dengan memanfaatkan teknologi komputer juga mengoptimalisasi dalam pegolahan data judul yang diajukan oleh mahasiswa. Sistem pengajuan judul skripsi ini dirancang dengan menggunakan Bahasa PHP dan database MySQL. Sistem ini dirancang dengan menggunakan model perancangan prototyping.

Tahapan-tahapan perancangan model prototyping yaitu, analisis dan pengumpulan data sistem, membangun prototyping, pengkodean sistem, pengujian sistem dan penerapan sistem. Proses perancangan diawali dengan menganalisis kebutuhan dengan melakukan wawancara secara langsung kepada dua dosen yang termasuk dalam tim seleksi jurusan, staf jurusan dan mahasiswa Jurusan Pendidikan Teknik Elektro FT UNM, wawancara dilakukan dengan menggunakan panduan wawancara yang berisi tentang bagaiama kondisi sistem yang berjalan sekarang, pendapat mengenai jika akan dibangun sistem digitalisasi pengajuan judul mahasiswa serta proses yang dibutuhkan dalam penerapan sistem digitalisasi pengajuan judul skripsi mahasiswa di Jurusan Pendidikan Teknik Elektro FT UNM. Setelah dilakukan wawancara kemudian dilakukan perancangan use case, flowchart, data flow diagram, activity diagram dan entity relationship diagram yang menggambarkan sistem yang akan dibangun, kemudian dari rancangan tersebut disusunlah tampilan sistem informasi sesuai dengan alur kerja sistem.

SIMPEL mempunyai jenis user yang berbeda dengan kemampuan akses yang berbeda. Admin merupakan pengguna utama yang dapat mengolah seluruh data dalam sistem, pada halaman admin dua menu utama yaitu master dan data pengajuan, pada menu master terdapat 4 submenu yakni penanda tanganan, data dosen, pengguna dan memo, sedangkan pada data pengajuan memiliki dua submenu daftar rapat dan daftar pengajuan. Halaman dosen terdapat dua menu yakni, beranda dan seleksi, pada menu seleksi, tim seleksi judul dapat menyeleksi judul secara online, jika judul diterima tim dapat memilih salah satu judul yang dimasukkan, serta memilih pembimbing dan penguji. Halaman mahasiswa terdapat beranda dan pengajuan, pada menu beranda mahasiswa terdapat informasi pengumuman, data judul yang diterima dan data judul ditolak, sedangkan pada menu pengajuan terdapat submenu identitas mahasiswa yang berisi nama lengkap, nim, penasehat akademik, program studi dan jurusan, submenu judul di mana mahasiswa memasukkan tiga judul yang akan diajukan, kemudian pada submenu kelengkapan mahasiswa dapat mendownload berkas pengajuan dan melengkapi dan dilanjutkan dengan mengupload berkas yang telah dilengkapi dan pada submenu finalisasi mahasiswa harus memastikan berkas maupun judul yang dimasukkan pada akun dan kemudian menyimpan.

Pengujian sistem SIMPEL ini dilakukan dengan beberapa tahapan, adapun beberapa tahapannya yakni, validasi ahli (expert), dan tanggapan pengguna (user). Berdasarkan kedua tahapan pengujian tersebut, diperoleh hasil bahwa SIMPEL layak untuk diimplementasikan. Hal ini terlihat dari hasil pengujian yang telah dilakukan di mana semua kriteria evaluasi hasil pengujian berhasil. Oleh karena itu, SIMPEL dikatakan dapat berjalan dengan baik sesuai dengan kriteria rancangan sebelumnya. Validasi expert yaitu meminta tanggapan dan saran dalam pengujian yang dilakukan oleh dua orang ahli sistem, dua orang ahli konten yang bertugas untuk memberi penilaian terhadap sistem informasi yang telah dibuat dan menunjukkan hasil yang baik dan layak untuk diimplementasikan. Selain itu, responden atau pengguna memberikan tanggapan sistem yang telah dibuat menunjukkan hasil yang baik dan layak untuk diimplementasikan.

Pengujian sistem dilakukan dengan menggunakan standar ISO/IEC 25010 sebagai acuan pengujian. Terdapat 5 aspek yang digunakan dalam pengujian yaitu, fungsionality suitability, usability, efficiency, reliability dan maintability. Hasil pengujian kualitas perangkat lunak dari sisi fungsionality seperti yang terlihat pada tabel hasil pengujian fungsionality dan dapat disimpulkan bahwa SIMPEL dapat diterima dalam segi fungsinya.

Kemampuan yang berhubungan dengan penggunaan perangkat lunak, kemudahan dalam menggunakan fungsi-fungsi yang diberikan, kemudahan mempelajari sistem dan kepuasan dalam menggunakan SIMPEL. Pengujian dengan menggunakan kuesioner yang diberikan kepada pengguna, berdasarkan hasil perhitungan diperoleh rata-rata $89,25 \%$ yang termasuk dalam kategori sangat layak dapat dilihat pada tabel hasil pengujian usability rentang skor skala likert dan interpretasinya menunjukkan bahwa SIMPEL dapat diterima oleh pengguna.

Pengujian efficiency pada SIMPEL dilakukan secara online dengan link: https://gtmatrix.com. Pengujian ini diperuntukkan melihat tingkat efisiensi dari aplikasi yang diuji coba. Tools yang digunakan untuk pengujian ini yaitu, YSlow dan Pagespeed Insight dan time yang di mana memuat tools yang fungsinya untuk menganalisis halaman web dan mengintesvigasi hal-hal yang menyebabkan load halaman menjadi lambat berdasarkan yahoo rules untuk meningkatkan performa website. Hasil dari pengujian $36 \%$ YsLow sebesar $54 \%$ dan waktu load sebesar 3.16 detik. Pengujian efficiency dikatakan berhasil karena waktu load kurang dari 10 detik.

Pengujian reliability pada SIMPEL dilakukan dengan menggunakan metode stress testing. Stress testing adalah salah satu metode pengujian software yang menentukan ketahanan suatu software dengan menguji di luar batas penggunaan normal. Stress testing dapat diuji dengan menggunakan web testing tool yang bernama webserver stress tool, yang memiliki rasio keberhasilan $100 \%$ pada SIMPEL. Sehingga dari hasil tersebut pengujian pada aspek reliability sudah memenuhi.

Pengujian maintainability pada SIMPEL diuji secara langsung, apabila terdapat kesalahan masukan yang dilakukan oleh pengguna, maka sistem secara otomatis akan memberikan pesan peringatan kesalahan. Hasil pengujian menunjukkan bahwa sistem mudah untuk diperbaiki dan dikembangkan, karena dibuat menggunakan framework PHP berbasis modelview-controller 
(mcv). Jika ingin menambah fungsi, pengembang hanya perlu membuat controller baru tanpa mengubah komponen sistem yang lain. Ketika ditemukan error pada fungsi sistem. Kesalahan dapat ditelusuri bahwa pada bagian komponen modul/controller yang bermasalah. Contohnya jika fungsi penyimpanan data tidak berfungsi dengan baik, pengembang hanya perlu mencari kesalahan pada komponen modul penyimpanan data itu saja.

Berdasarkan hasil dari penelitian SIMPEL setelah dilakukan validasi dan pengujian dengan menggunakan ISO/IEC 25010 ditinjau dari segi fungsionality suitability, usability, efficiency, reliability dan maintability dapat disimpulkan bahwa SIMPEL dapat gunakan dan diterapkan di Jurusan Pendidikan Teknik Elektro FT UNM.

\section{KESIMPULAN DAN SARAN}

A. Kesimpulan

Berdasarkan hasil penelitian dan pembahasan, maka peneliti dapat mengambil kesimpulan sebagai berikut:

1. Sistem Pengajuan Judul Skripsi di Jurusan Pendidikan Teknik Elektro Universitas Negeri Makassar Berbasis Website dibuat sebagai media yang dapat mempermudah mahasiswa dalam pengurusan judul dan dapat melihat langsung status judul yang diajukan pada sistem, juga memberikan kemudahan kepada staf jurusan yang menangani pengajuan judul mahasiswa dalam pembuatan draft judul yang akan dirapatkan oleh tim seleksi judul serta mempermudah tim seleksi judul dalam verifikasi judul mahasiswa dan dapat memberikan komentar jika terdapat judul mahasiswa yang ditolak.

2. SIMPEL dinilai layak karena hasil pengujian menunjukkan bahwa SIMPEL telah memenuhi standar ISO/IEC 25010 dalam 5 aspek pengujian. Adapun hasil pengujian pada aspek fungsionality mendapatkan nilai 1 yang berarti berada dalam kategori "diterima". Pengujian aspek usability dengan jumlah responden sebanyak 40 memperoleh rata-rata persentase kelayakan sebesar 89,25 dengan kategori "Sangat layak". Pengujian aspek efficiency page speed sebesar $36 \%$ YsLow sebesar $54 \%$ dan waktu load sebesar 3.16 detik dikatakan berhasil karena waktu load kurang dari 10 detik. Pengujian aspek Reliability persentasi kesuksesan dengan menggunakan click test, time test dan ramp test adalah $100 \%$. Pengujian aspek maintainability diperoleh kesimpulan yang mudah diperbaiki apabila terdapat kesalahan.

B. Saran

Berdasarkan hasil dan pembahasan dalam penelitian, adapun saran yang diberikan oleh peneliti sebagai berikut:

1. Bagi civitas Jurusan Pendidikan Teknik Elektro Fakultas Teknik Universitas Negeri Makassar sebagai pihak yang akan menggunakan sistem ini diharapkan dapat segera mengimplementasikan sistem pengajuan judul skripsi ini, serta dengan penggunaan sistem ini nantinya dapat menyediakan informasi dan layanan yang jauh lebih baik.

2. Bagi peneliti lain atau pengembang, diharapkan dapat mengkaji lebih dalam dan mengembangkan system pengajuan judul (SIMPEL) sehingga sistem dapat mengikuti perkembangan zaman, menambahkan fitur yang lebih banyak, penggunaan tampilan yang lebih menarik dan interaktif, penambahan informasi jadwal perkuliahan yang lebih kompleks.

\section{DAFTAR PUSTAKA}

[1] Kamil, S. U. R., Amin, H., Saidin, S., \& Upe, A. (2019). The implementation of information and communication technology on learning process in communication department of uho facing industrial revolution 4.0 [penerapan teknologi komunikasi dan informasi pada pembelajaran jurusan ilmu komunikasi uho menghadapi revolusi industri 4.0].

[2] Rachmaniar. 2017. Sistem Tata Kelola Laboratorium Jurusan Pendidikan Teknik Elektro Fakultas Teknik Universitas Negeri Makassar. UNM: Makassar

[3] Niswatin, R. K., \& Sanjaya, A. (2017). Sisteminformasi berbasis web untuk klasifikasi kategori judul skripsi. Prosiding SNATIKA, 4, 5055 .

[4] Ogedebe, P.M.,\& Jacob, B.P. , 2012, Software Prototyping: A Strategy to Use When User Lacks Data Processing Experience. ARPN Journal of Systems and Software. Vol. 2, No.6

[5] Pressman, R.S. 2002. Rekayasa Perangkat Lunak: Pendekatan Praktisi(Buku Dua). Yogyakarta: Penerbit Andi

[6] Alfian, Irfan. 2017. Analisis Kualitas Ssitem Aplikasi M-Library di Perpustakaan Uviversitas Gajah Mada. Universitas Gajah Mada: Yogjakarta 